\title{
Unscientific Methods: Reinvigorating Objectivity in Politics
}

Alyssa Lieberman

Finding a place for objective science within the realm of American politics has become increasingly difficult because the effective use of rhetoric can often obscure facts. Both Republicans and Democrats are guilty of pushing scientific recommendations to the wayside when it suits their political needs. The debate over the use of Yucca Mountain as a site for the storage of nuclear waste, for example, has shown how shortterm political goals of reelection can impede the implementation of scientific recommendations.

Yucca, a spot in the middle of the Nevada desert, was recommended as a site for the storage of nuclear waste because it is sparsely populated and near a former site of government-conducted underground nuclear tests. ${ }^{1}$ Although nuclear waste is minimal (the industry produces only 2,000 metric tons of waste annually) and can be disposed of through secure means, the decision of where to store it became controversial. ${ }^{2}$ Ideally, the approval of Yucca as a nuclear waste site would have been uncontested.

A bi-partisan panel concluded that deep geological disposal - the proposed method for Yucca - was the best option for handling nuclear waste, and scientists have recommended this process as well, citing the creation of distance between waste, biosphere and long-term function. ${ }^{3}$ Despite this, 75 percent of the Nevada population spoke out against the project. ${ }^{4}$ And because their constituents' short-term disapproval could have resulted in dire political consequences, many politicians, from Nevada Sen. Harry 
Reid to then-presidential candidate Barack Obama, rejected the site as unfit.

The GOP's unwillingness to look at scientific facts, by contrast, can be explained by the party's stance on big government. Republicans stand firmly against most regulatory policies, which they view as excessive government interference. Hostility towards regulations on scientific matters is a natural extension of the party's opposition to government oversight, which has most recently been shown in Kentucky Sen. Rand Paul's comments on vaccines.

Amidst the national outbreak of measles, Paul emphasized the importance of voluntary vaccination because he believes "the state does not own your children." His stance against regulation led him to express concern over cases of "normal children who wound up with profound mental disorders after vaccines," despite his medical background. ${ }^{5}$ Paul may not personally oppose vaccines, but he chose to take a stand for fear of being criticized of supporting regulation. In doing so, he misrepresented the issue by portraying vaccines as a fanatical issue instead of common sense. Though the study that linked autism and vaccines was famously discredited several years ago, Paul's ideology convinced him to hang onto a baseless scientific view that flies in the face of medical consensus. ${ }^{6}$

Republican animosity towards regulation, however, is both pragmatic and principled. The party is against government interference in the American economic sphere because of its strong ties to corporate America, which feels profits are threatened by government regulation. Many Republican candidates receive funding while running for office from large corporations, and an accidental information release this past September illustrated just how close the Republican Party and corporations have become: Since 2008, some of the most prominent American companies have donated millions to the Republican Governors Association in exchange for meetings with and influence over governors. ${ }^{7}$

Corporate interest does not stop at the state level, though. It also extends to the Republican Congress, which rang in 2015 with attempts to decrease financial regulations on Wall Street. ${ }^{8}$ Although the Democratic Party has corporate ties as well, theirs are not nearly as strong. In 2014 , only one of the top three contributors to Democratic federal campaigns was a corporation. The top corporate donor to 2014 Democratic campaigns was Newsweb Corp, an ethnic and alternative newspaper without clear economic prerogatives. $^{9}$ Because the Democratic Party's interests are not as intertwined with those of corporations threatened by regulation, the party is more supportive of environmental issues, such as climate change.

Several corporations financing Republican campaigns have strong ties to the fossil fuel industry, a connection that pushes most Republicans in Congress to deny climate change. ${ }^{10}$ The party subsequently projects these views onto voters by framing global warming as a non-issue. Unlike the Democratic Party, Republicans ignore the science behind climate change, claiming it is simply a belief, like a religion, rather than fact. ${ }^{11}$ Further, to distance voters from the subject, Republicans speak about global 
warming in abstract terms, often misinterpreting it in the process. Instead of recognizing the negative economic consequences, such as damage from increased flooding or damage to crops from droughts, the party falsely links progress in the environmental sector with negative economic growth. ${ }^{12}$ In his 2012 campaign, Romney mocked Obama's pledge "to heal the planet," saying that instead of fighting climate change, he would help American families. ${ }^{13}$ This misinformation on global warming is common among Republican politicians: Oklahoma Sen. Jim Inhofe, a longstanding member of the Senate Committee on Environment and Public Works, displayed ignorance on what climate change entailed when he presented a snowball to his colleagues as "proof" that global warming was a "hoax." 14

Though 97 percent of scientists firmly believe that global warming is real and agree that "climate-warming trends over the past century are very likely due to human activities," two-thirds of Republican voters classify climate change as a non-existent or minor threat to the United States. ${ }^{15,}{ }^{16}$ A recent Senate vote on whether or not climate change was a hoax passed only because Sen. Inhofe instructed the members of his party to vote in favor of the amendment, his argument being that its loose language allowed Republicans to come across as slightly progressive without compromising their stance on the issue. ${ }^{17}$ Sen. Inhofe stated that "the climate is changing," before adding that "the hoax is that some people think they are so powerful they can change climate." Other amendments acknowledging humans' role in climate change, however, did not pass, with only five Republicans agreeing that humans significantly impact climate change. ${ }^{18}$ ***

These various stances also translate to Republican policies on energy and fossil fuels. This can be seen in the recent 'tax extenders' proposed by Congressional Republicans. This agreement not only supports a Wall Streetdominated economy with bonus depreciation, but attempts to dismantle the innovative and successful wind energy industry. Though the energy is a clean and renewable source, a wind production credit is one of the few tax credits not extended by the Republican deal. The GOP would rather endorse their ally, Koch Industries, than an alternative solution, despite the fact that the wind energy industry employs 50,000 Americans.

Similar issues are also at the heart of the debate surrounding the Keystone Pipeline. The proposed Keystone $\mathrm{XL}$ pipeline is an expansion of the Keystone, which runs from Alberta, Canada to Oklahoma. The project would add 1,700 miles, with a connection from Oklahoma to Texas, and an additional section that would transport tar oils from Alberta, Canada to Kansas. Republicans, who advocate for its completion, emphasize the economic impact that could result, and make note of the increased access to oil it would provide. ${ }^{19}$ Most Democrats, by contrast, firmly reject the approval of the pipeline due to its potential contributions to global warming and possible pollution.

The added segments would raise the transportation of oil from tar sands, which have a higher rate of carbon emissions, from 590,000 to 1.1 million tons a day. ${ }^{20}$ The 
increase in carbon emissions, estimated as high as 121 million tons per year, will further exacerbate global warming. Yet, the significance of this increase depends on politicians' beliefs. ${ }^{21}$ Depending on political values, this increase is framed as either a contributing factor in a dangerous trend or as an insignificant figure. Most Republicans cite that 36 billion tons are already emitted each year, and they overlook the increase to focus on other possible effects that would be more tangible and immediate, such as the creation of construction jobs or independence from foreign oil. ${ }^{22}$ But for those who think of global warming as a threat to American well being, the sizable increase is grounds to reject the bill.

Unfortunately, those in positions pertinent to environmental and scientific issues are often ignorant and give subjective interpretations to scientific facts. For example, the House Committee on Science, Technology and Space has several members that are disconnected from scientific findings. One member, Rep. Paul Broun, describes evolution as "lies straight from the pit of hell."23

The Senate faces a similar problem: Sen. Ted Cruz, an ardent climate change denier, chairs the Senate Space, Science and Competitiveness subcommittee. His plan to focus NASA on space exploration is contingent on his view that global warming is not real. Instead of proposing increased funds to allow greater space exploration, Cruz plans to downsize the meaningful work NASA does in monitoring climate change and its effects on our planet. According to the senator, NASA satellites that have helped to predict floods, droughts, and weather are unnecessary. ${ }^{24}$ Cruz argues that there has been no recorded climate change for the past 15 years, despite the copious amounts of scientific evidence that state otherwise. ${ }^{25}$

Additionally, in spite of its name, the Committee on Science, Space and Technology directly hinders scientific progress, as its members interfere on matters they are unfamiliar with. For example, the committee has attempted to interfere with the National Science Foundation's grant choices. It claims that funds were being spent on projects that did not serve the national interest. The members did not, however, understand the true purpose of the projects they were attempting to dismantle.

Many of the projects the House dubbed as "outside national interest" were in fact extremely relevant to their fields. Sen. Tom Coburn attempted to revoke funding for the Fossil Project. He believed it to be nothing more than a "Fossil Facebook," but in reality this project greatly benefited the Paleontology community and allowed amateur fossil hunters and professionals to collaborate so that a greater number of specimens could be digitized. ${ }^{26}$ The committee made assumptions without considering the scientific quality and importance of the programs it designated unnecessary. 27

To fulfill their obligation to protect the American people and further American progress, politicians must stop interpreting hard scientific facts as it suits their political needs. They must begin to thoughtfully translate scientific data into legislation and policies so that pertinent topics can be addressed and the true needs of the American 
people can be met. The honest evaluation of this data is a formidable and seemingly unrealistic goal but, if nothing else, a moral

1 Geoffrey Brumfiel, "America's Nuclear Dumpsters, 》 Slate, January 30, 2013, Internet (accessed February 20, 2015).

${ }^{2}$ Nuclear Energy Institute, "On Site Storage of Nuclear Waste," Internet (accessed February 20, 2015).

3 European Parliament. "Considerations on Deep Geological Disposal." December 10, 2010. Internet (accessed February 20, 2015).

4 Geoffrey Brumfield, "America's Nuclear Dumpsters", (accessed February 20, 2015).

5 "Resorting to Freedom," The Economist, February 4, 2015, Internet (accessed February 20, 2015).

6 Matthew F. Daley and Jason M. Glanz, "Straight Talk About Vaccination," August 11, 2011, Internet (accessed February 20, 2015).

7 Jonathan Weisman, "G.O.P. Error Reveals Donors and the Price of Access," The New York Times, September 14, 2014, Internet (accessed February 20, 2015).

8 Danny Vinik, "The Republican Has Done Nothing But Help Big Business," New Republic, January 15, 2015, Internet (accessed February 20, 2015).

9 "Top Individual Contributors: All Federal Contributors," Open Secrets, Internet (accessed February 20, 2015).

10 Lee Fang,"Midterms 2014: Candidates Dodge and Deny Threat of Climate Change," October 27, 2014, Video, Internet (accessed February 20, 2015). standard must be enforced for publicly elected officials to serve in the best interest of the American people.

11 Rebecca Laber, "You Can't Believe in Climate Change," New Republic, March 10, 2015, Internet (accessed February 20, 2015).

${ }^{12}$ Diana Liverman and Amy Glasmeier, "What Are the Economic Consequences of Climate Change?," The Atlantic, April 22, 2014, Internet (accessed February 20, 2015).

13 Al-Jazeera English, "Mitt Romney and Climate Change," November 1, 2012, Video, Internet (accessed February 20, 2015).

14 Timothy Cama, "Inhofe Hurls Snowball on Senate Floor," The Hill, February 26, 2014, the Internet (accessed February 20, 2015).

15 "Wide Partisan Divide Over Global Warming," Pew Research Center Webpage, October 27, 2010, Internet (accessed February 20, 2015).

16 "Consensus: 97\% of Scientists Agree," National Aeronautics and Space Administration, Internet (accessed February 20, 2015).

${ }^{17}$ Suzanne Goldenberg, «US Senate Refuses to Accept Humanity's Role In Climate Change, Again," January 22, 2015, Internet (accessed February 20, 2015).

${ }^{18}$ Laura Barron-Lopez, "Inside the Senate's Big Vote on Whether Climate Change is Real, » The Hill, February 2, 2015, The Hill, Internet (accessed February 20, 2015).

${ }^{19}$ Violet Rogers and Jack Ethridge, "Keystone XL Pipeline," Journal of International Energy Policy, June 2014, Internet (accessed February 20, 2015).

${ }^{20}$ Violet Rogers and Jack Ethridge, "Keystone XL Pipeline," Journal of International Energy 
Policy, June 2014, Internet (accessed February 20, 2015).

21 "Study: Keystone Pollution Higher," Politico, August 10, 2014, Internet (accessed February 20, 2015).

22 "Study: Keystone Pollution Higher," Politico, August 10, 2014, Internet (accessed February 20, 2015).

${ }^{23}$ Jillian Rayfield, "Least Scientific Members of the House Science Committee," Salon, October 8, 2012, Internet (accessed February 20, 2015).

${ }^{24}$ Rebecca Leber, "Ted Cruz is Poised to Become a Lead Senator on Science," New Republic, November 6, 2014, Internet (accessed February 20, 2015).

${ }^{25}$ Rebecca Leber, "Ted Cruz Wonders Why NASA Scientists Should Study Planet Earth," New Republic, March 12, 2015, Internet (accessed February 20, 2015).

${ }^{26}$ Scott Johnson, "Fruitful Fossil Database Targeted by US House Science Committee," Ars Technica, January 15, 2015, Internet (accessed February 20, 2015).

27 Timothy McNulty, "Critz Defeats Altmire," Pittsburgh Post Gazette, March 28, 2012, Internet (accessed November 8, 2012). 